\title{
Articles
}

\author{
Alexander Kazankov
}

\section{The "Last Times": The Perception of Time by Residents of the Russian Province in the First Half of the Twentieth Century}

\author{
Translation by Jan Surer
}

DOI: $10.22394 / 2311-3448-2016-3-2-4-25$

\begin{abstract}
Alexander Kazankov - Department of Cultural Studies, Perm State Academy of Art and Culture (Russia). tokugava2005@rambler.ru

This article presents a phenomenological interpretation of the experience of time by the inhabitants of villages and small towns in the western Urals. The study draws upon primary sources from the Perm State Archive of Contemporary History. The author's aim is to analyze investigation files of Orthodox clergy and other "church people" and to identify mental structures related to the perception of time. The primary structure that defined the basis of time orientation was the tradition of the annual Church calendar of feasts and fasts. The secondary structure was the idea of the "three ages of life," sometimes marked by rites of passage. A special feature of the perception of time was a clear rise of apocalyptic expectations at the turn of the 1920s1930 ("the last times are coming").
\end{abstract}

Keywords: Orthodox Church, the clergy, "church people," time, Soviet Russia.

7 HE anthropological turn taking place right before our very eyes in the humanities in Russia allows us to formulate questions that would be impossible within the framework of other research strategies. Here, for example, is one such question: How is 
religion present in the believer's life beyond actual worship practices or food prohibitions? Alternatively, this question can be expressed as follows: What kind of "centers of gravity [Schwerpunkte]" has faith occupied in the domain of everyday life, what kind of influence has it shown and does it show on the "pattern" of usual, habitual behavior (habitus) of this or that individual?

This question opens up extremely broad scientific horizons. Recently in personal conversation with researchers on Protestant-Pentecostal communities I asked what was distinctively "Pentecostal" in their way of life and received an answer that amounted to the following: "They don't drink, they don't smoke, they hold prayer meetings." Beyond this answer the question remains whether their faith influences rhythms of work and rest, their production, communication, and leisure practices, whether (and how) it influences their consumer strategies, their choice of a place of residence, marital or sexual partner, reading matter, and so forth.

A meticulous description of all the aspects of daily life indicated above would have undeniable value, and such a description presupposes the development of a specific anthropology that closely encompasses the believer - even, perhaps, not one but multiple anthropologies, distributed by confession and denomination, by place, time, and gender, and pertaining to different lifeworlds.

In fact, the concept of "lifeworld" was also developed at a certain point in the phenomenological tradition to describe the reality "given" in lived human experience in anthropological terms. In other words, the prospect lies open for the fruitful "grafting" of phenomenological anthropology onto religious studies. The thick description of mentality - of the general orientations and habits of people's consciousness, of their "psychic instrumentation," their "spiritual equipment," in the words of Aron Gurevich - assumes special significance in this context. It is precisely this mentality that plays the role of the unique "translator" or "exchange mechanism" between religious doctrine and everyday practices, encoding the basic meanings of human experience (for example, see Astakhova 2013).

The development of these anthropologies in Russian religious studies is certainly underway. Among the works closely related to the present topic I wish to note that of Aleksei Beglov (Beglov 2008), in which he presents an interpretation of daily life as seen through the eyes of "church people." Beglov's interest has definitely shifted toward the time period following the Second World War. Elena Kondrashina's publication provides an example of a gender approach (Kondrashina 2014). 
Pavel Protsenko's research constitutes an excellent foray into the use of the biographical method, dealing with everyday life and the horizons of the lifeworld (Protsenko 2010). Protsenko had rare good fortune Bishop Varnava (Beliaev), a product of the "learned monasticism" of the pre-revolutionary era, practically prepared the materials for his biography himself in that he kept a diary through his whole life and actively engaged in photography; Protsenko had what proved to be authentic sources of personal provenance at his disposal.

This latter case, however, points to specific difficulties of this sort of research agenda. The standard anthropological approach, oriented toward a close or thick description of the world of meaningful, everyday practices, and working with such delicate materials as the lived experience of the perception [vospriiatie], or experience [perezhivanie] of natural and social reality, the structure of mentality, and the like, requires a certain quality (and indeed quantity) of sources. Human identity (subjectivity) in its utmost individuation must be implicit in these sources. Sources that meet these requirements can be divided into two groups: sources of personal origin and the findings of participant observation, which involve lengthy discussions with informants.

The present research focuses on the perception (or experience) of time in provincial everyday life in the first half of the twentieth centu$r y$, but the "surveillance camera" will be fixed on a very specific group Orthodox "church people" of the Western Urals, now Perm Krai. First, I shall present the arguments that motivated this choice. Most notably, the perception of time is one of the basic structures of mentality, a sort of "anthropological constant" shaping a person's external as well as internal experience. Furthermore, the territory of present-day Perm Krai can be considered as a sample Russian province; in this respect the Western Urals are conveniently situated midway between the capital centers and extremely remote outlying regions. I chose the first half of the twentieth century for understandable reasons - in Russia this was an era of social, political, and cultural transformations on a colossal scale that touched the very foundations of human existence and therefore inevitably engendered repercussions in everyday experience and ordinary practices. And finally, my "focus group" was defined not by chance but in connection with the extremely critical (from the perspective of research planning) problem of sources.

A person can voluntarily convey his everyday experience in discourse, leaving "clues" for future researchers, as if questioning himself. In such a case the person shares experience of the past in diaries, writes letters, collects photographs in albums, or writes memoirs (in which, 
incidentally, the author often consciously lies and fantasizes). Unfortunately, I had no such sources at my disposal. It is difficult even to imagine a memoir by a peasant of a village such as Asovo or Ust-Kishert, or a diary by a resident of the Alexandrovsky or Yugovsky factory settlement, established in the first half of the twentieth century. Nor did I possess even similar descriptions composed by outside observers.

But another situation is possible: one can question someone (an informant) under compulsion. Those who had the right and even were obligated to interrogate people were the inquisitor and the investigator. The experience of Emmanuel Le Roy Ladurie and Carlo Ginzburg working with the Inquisition archives also attests that the work of inquisitors of all sorts is to some extent related to anthropology (see Le Roy Ladurie 2001 and Ginzburg 2000). Now it becomes clear why the milieu of "active church people" presents an ideal "observation post." I shall introduce the sociopolitical context in order to decisively "leave it aside" hereafter. "Church people" (parish priests, deacons, psalmists [psalomshchiki, i.e, chanters], former monks and nuns, "church activists," itinerant preachers, holy fools, beggars and the like), finding themselves in a situation of permanent social catastrophe in Soviet Russia and balancing on the narrow, barely perceptible edge of legality, had to possess a keen sense of the events happening in the world around them. As we shall see, an astonishing mobility, common to the marginalized, distinguished them. That being said, thanks to their strong peasant roots and rich lived experience they enjoyed a huge reserve of vitality that permitted them to adapt to the most trying conditions of existence. Indeed, for two decades they were subject to repression with surprising regularity, in the course of which extensive and at times very informative "interviews" were conducted - the reports of these interrogations, moreover, were authorized, insofar as at the end of each was placed the phrase: "This report of my words was written down accurately and read by me, to which I affix my signature."

A final comment concerning sources: The "inquisitors" of district offices of the NKVD in what is today Perm Krai were poorly educated, not very curious, very biased and impatient. They did not wait until "heresy" found expression in the spontaneous talk of the one being questioned, but boldly introduced the heresy into the conversation. Fortunately, it is not difficult to set aside this layer of discourse introduced into the speech of those being interrogated from radio broadcasts, lead articles in newspapers, party meetings, and courses for junior officers. First and foremost, stammering and an abundance of dialecticisms (galakhi [tramps, vagabonds, drunks], kaliuzhina [a garbage pit], spu- 
chit [to blow] and the like) and idiomatic expressions (of the type "Sovetskaia vlast', necha v kvashonku klast" - "Soviet power [leads to the fact that] there's nothing to put in your kneading bowl") distinguished "spontaneous" everyday speech. Imitating this was outside the brief of an NKVD investigator. Instead, the most prevalent technique in an interrogation was precisely the coerced "recoding" of everyday discourse.

When addressing the accused or a witness, the investigator explicitly indicated to the interviewee how to label correctly whatever was under discussion, drawing the person into a peculiar language game. For example, after a story about an ordinary, everyday drinking bout, there followed the question: "Who else was present at your counterrevolutionary gathering?" And upon a story about "an explanation of the Antichrist" came the question: "Who directed you to conduct this anti-Soviet agitation?" In the majority of cases the interviewee accepted the proposed nomenclature, but did not change the testimony's content - the drinking bout looked like a drinking bout, and the sermon - just like a sermon.

Another recognizable device was the "novella," composed by the investigator and subsequently imported into the statement. A distinctive sign of the "novella" was always the presence of topical political vocabulary and the author's unquestionable possession of at the very least minimal - if not bookish, then "newspaper" - culture. In a note the priest I. Kotel'nikov articulated well the relationship of a typical representative of the village clergy in the Western Urals to reading: "Read the Gospel the acts the epistles of the Holy Apostles but other books do not read, other books are all fit only for wiping your backside on the toilet yes only the baper in them is rough" (PermGANI, f. 641/1, op. 1, d. 8768, t. 1, l. 10-ob.) (preserving the orthography and punctuation of the original). ${ }^{1}$

The key circumstance is this: The "inquisitors" were not particularly zealous in falsifying testimonies before August 1937 - the moment when large-scale operations began. Therefore, the present article uses as sources the testimonies of sixty-seven priests, deacons, church elders, and the like, involved in individual and group cases as the accused and as witnesses. ${ }^{2}$

1. This English version attempts to approximate the misspellings and absence of punctuation in the original. It renders "paper" as "baper" because the Russian word for paper, bumaga, is written as gumaga - Translator.

2. The documents used in the present article are derived from archival investigative files held in the Perm State Archive of Contemporary History in collections (fondy) 641/1 and $643 / 2$. These documents directly bear witness to the application of repression against citizens for political reasons: arrest warrants, decisions concerning pre-trial 
Analysis of statements about time in these sources makes it possible to distinguish quite definitively three meanings that this difficult-to-isolate phenomenon had in provincial everyday life in the Western Urals in the first half of the twentieth century. To start I shall interpret each of these meanings separately and then in their connection with each other and with the arena of everyday experience. First, there is the "little cycle" of time, defined by the annual rhythm of church holidays and fasts. Second, there is the "big cycle," experienced as the ages of life. And, finally, third there is the "universal cycle," linked with the sense of the approach of the last times, the end of the world, and the coming of the Antichrist.

In 1937, while answering an investigator's question about events that occurred two years earlier, semiliterate peasant woman Pelageia Novoselova (from the Novoselovo village), née Zomareva, makes an interesting amendment to her statement. She dates her brother Varlaam's return from exile incorrectly, and she corrects herself: "I must ask pardon from the investigator because in regard to Varlaam Zomarev I gave the wrong evidence when I said that he arrived from exile in 1934. In fact Zomarev returned from exile in 1935 around Easter - in the third or fourth week of the fast" [Here and hereafter italics are mine. - A. K.] (PermGANI, f. 641/1, op. 1, d. 12702, t. 1, 1. 113ob.). Naturally, she is conversant with the calendar and knows the months and the days of the week, but Pelageia Vasilevna can remember the exact date of an individually significant event only having "tied" it to a semantically privileged event of the Christian annual cycle - Easter.

The testimony of the priest of the village Ust-Kishert, Vasily Maksimov, gives a similar picture, as he explains when the itinerant preacher Mikhail Morskovatykh appeared among them in church the last time: "He was with us at the end of 1932 on St. Nicholas's Day, about December $19 ;^{3}$ he stayed for about two days and at the same time in 1933 he stayed for about two to three weeks" (PermGANI, f. 643/2, op. 1,

restrictions, forms on those arrested, reports of searches and interrogations of the accused and of witnesses, secret dispatches, memoranda, indictments, sentences, petitions from the accused, applications for case reviews, decisions on rehabilitation, and the like. A special group of documents from these closed criminal cases consists of so-called "hard evidence" - leaflets, appeals, letters, programs with "counterrevolutionary content." All the cited documents were written by hand with an ordinary fountain pen on low-quality paper and only sometimes were copied in type.

3. From February 1918, when the Soviet state mandated the use of the Gregorian calendar (the calendar in use in the West), the Russian Orthodox Church continued to use the Julian calendar, which was thirteen days behind the Gregorian calendar in the twentieth century. Thus St. Nicholas's Day (December 6 on the Church calendar) occurred on December 19 - Translator. 
d. 28183 , t. 1, 1l. 151-54). The priest remembers precisely that Morskovatykh - a conspicuous, disreputable figure in his time and place arrived in Ust-Kishert exactly on St. Nicholas's Day, but he finds it difficult to relate that to the calendar - "about December 19."

Comments of this sort are interesting because they demonstrate the mechanism of "hitching" the impersonal calendar cycle to a meaningful, "deeper" level of time perception - the church-holiday level, which refers the discussion directly to the culture of traditional society. This is because, if Emmanuel Le Roy Ladurie's conclusion based on European data is correct, by the fourteenth century, "the peasant calendar was dominated by the church calendar: religious acculturation in this sphere became irreversible (even today in our society that considers itself agnostic the arrangement of the calendar continues to be that of the church)" (Le Roy Ladurie 2001, 339). The second part of the French historian's thesis is not completely valid for Russian society - the Soviet era succeeded in "recoding" everyday time perception, leaving behind its signs and symbols in the form of the "First of May (Pervomai)," "FebMarch (Fevramart)" and the like, which stubbornly "hang about" there to this day, despite all attempts at a second recoding. ${ }^{4}$

One encounters simpler examples of the direct correlation of events to the church calendar at every step. Here is an example in which the chair of the Salomatovsky village soviet Stepan Tretiakov, by no means a church person, slanders the priest hieromonk Nifont (Agafonov) and the deacon Mikhail Ovchinnikov: "On July 9 on the feast of the Tikhvin Mother of God they with Hieromonk Nifont were guests of Ivan Maksimovich Shulikhin, the disfranchised kulak from the little village Zaozere, where they got so plastered that the deacon and monk fell asleep right there at the table and got sick all over everything" (PermGANI, f. 641/1, op. 1, d. 8891, l. 14). Tretiakov has no difficulty remembering both the date and the church holiday corresponding to it; in this case, the shocking behavior of the "deacon and monk" is the more memorable link, joining them into one. Here let me note that this presents us with an intriguing interpretive prospect - to what extent the sight of clerical individuals drinking heavily was an everyday occurrence in the residents' experience at that time.

Note, for example, that Mikhail Morskovatykh explains that not all Sundays are the same, which he easily relates to the calendar: "I was

4. Pervomai refers, of course, to the May Day holiday. Fevramart refers to the period between the paired holidays of Soviet Army and Navy Day (now Defenders of the Fatherland Day) on February 23, and International Women's Day (March 8) Translator. 
in the apartment of the priest of the village Novaia Osetrova about three times, the first time in February 1934 on an ordinary Sunday, and the second time somewhere in the first days of April 1934 on St. Thomas's Sunday [Low Sunday] (PermGANI, f. 643/2, op. 1, d. 28183, t. 1, ll. 88-96).

All attempts to uncover references to time periods smaller than this or that day have come to nothing. There is no "morning," nor "evening," "before lunch," "at dawn," "at noon" or the like in the sources. This creates the impression that in the everyday life of that time such categories simply did not exist, and this is all the more strange, given that in the lists of items confiscated during searches watches or clocks appear from time to time. For example, found in the possession of the itinerant preacher Foty Mikhailovich Petrov were: "a loaded, single-barreled pistol, books - Gospels - of different sizes - sixteen items, a silver pocket watch, a passport and assorted correspondence" (PermGANI, f. 643/2, op. 1, d. 28183, t. 1, 1. 14). The dean (blagochinnyi) Semen Apollonovich Nekrasov possessed "an old wall clock" (PermGANI, f. 641/1, op. 1, d. 12702, t. 1, l. 135). A "wall clock with a chime," worth fifteen rubles, along with a "female goat named Manka," belonged to Pavel Alexandrovich Shliapnikov, who had formerly been a priest; in 1937 he was a tailor in an artel for the disabled (he was a dwarf; in his arrest form in the section for special remarks, "height 140 centimeters" was noted) (PermGANI, f. 641/1, op. 1, d. 12702, t. 1, 1. 251). By the way, fifteen rubles was a very modest sum - lined felt boots, an utterly ordinary object of everyday use in Ural winters, cost approximately three times as much.

It is possible that this "blurring" of intra-day rhythms was influenced by the resolution of the Presidium of VTsIK (the All-Russian Central Executive Committee) of December 16, 1929, "On the regulation of bell ringing in churches," which effectively deprived church bells of their voice. Indeed, in the culture of traditional society (which is precisely the cultural image the sources depict), it was the very ringing of bells, according to Jacques Le Goff, that provided the rhythm of alternation between work and amusements, prayer and idleness: "The ringing of the bells, calling priests and monks to service, was the sole means of reckoning the time of day" (Le Goff 2005, 221).

Only once did the literate and church reader Mikhail Morskovatykh, specifying the circumstances of sessions he held on the "coming of the Antichrist," indicate [time of day]: "Giving explanations of these matters to separate believing workers from the collective farms, to individual farmers, and to groups of up to five people - I usually conducted these group discussions in the Ust-Kishert church between services, 
between the morning service and divine liturgy" (PermGANI, f. 643/2, op. 1, d. 28183 , t. 1, ll. 82-87). From this it is evident that the "intraday" chronological partitioning of routine experience in the sole recorded case also follows the church service order. And note that there is no trace of the influence of, let us say, a work ethic ("before work," "after work" and the like).

The deeply internalized "short" rhythms of annual holidays and fasts gradually develop into more extensive cycles that, according to Philippe Ariès, can be called the "ages of life." (See Ariès 1999.) Ariès was able to count four or five of them. In the everyday life of the inhabitants of the western Ural villages and hamlets there were fewer, with only three clearly distinguishable.

It is problematic to designate the first age as childhood, as no one ever labels it that way. Here are typical expressions of the first age: "I was born into a family of an independent artisan, a tailor. Until the age of twenty-one I worked in my father's trade - during this time, beginning from the age of eleven, in summers I lived with different peasants as a hired laborer, and in winter I worked in my father's business - and I did other seasonal labor, a raft loader and so forth" (PermGANI, f. 643/2, op. 1, d. 28183, t. 1, ll. 144-45), or the following: "I was born into a middling peasant family; until the age of twenty-two, that is, until 1895, I lived and worked on my father's land. In 1895 I separated from him and worked my own land until 1915" (PermGANI, f. 643/2, op 1, d. 28183, t. 2, ll. 2-4).

Most likely, to people born into peasant families of modest means, the first period of life, or the first age, denoted by the expression "I lived and worked in my father's trade," had a quite familiar meaning: This was a time when a person was the "property" of his parents. Neither school nor the state laid any claim on the individual, nor was the person "self-employed" (note the counterpoint: "In 1895 I separated from him and worked my own land") but was used for suitable work "wherever they send me."

As for the everyday meaning of the designation "children," "boy," and "girl," first, these terms signify what a person has: "I have children." Each man and woman indicates his or her children on the arrest form or in the report on the interrogation, expressing certain imperatives concerning them: "so that they would teach their children to pray to God" (PermGANI, f. $641 / 1$, op. 1, d. 8768 , t. 1, ll. 18-19ob.). To be sure, the meaning of such an assertion is two-fold - the children exist as mine (hence they simply exist as children), but I also own, I possess children. The interpretation given earlier makes the second meaning more likely. 
In addition, the designation "boy" (and for some reason it is just that - a boy and not a girl) can acquire the symbolic, sacred meaning of purity and innocence: "two boys had a vision," "two boys found a document behind the iconostasis and it said..." and the like. An adult might merit a vision only in an extreme state - during a severe illness, or at the point of death - such as, for example, "the foreman's vision about collective farm workers and individual farmers."5

And, finally, boys and girls were only just entering the everyday life of the Ural village in the 1920s-30s in conceptual association with Young Pioneer and schoolchild. In 1935 the policeman Kiriakov from the first precinct of Ordinsky district reported to the head of the NKVD district office:

I bring to your attention that on January 2, 1935, the Usanovsky priest ${ }^{6}$ was going around with holy water in the hamlet of Mikhailovka in the Mezhevsky village soviet. He carried the water in a teapot and stopped at each house, where he asked whether they were Orthodox or not. He stopped at the apartment of Fedor Ivanovich Kiriakov, who has three schoolchildren, one of whom is a girl pioneer. During the priest's time in the apartment the schoolchildren began to laugh, and at this the priest tells F. I. Kiriakov that it is not good to bring up children this way, and then there's this pioneer girl with her neck scarf, he said, don't raise them that way (PermGANI, f. 641/1, op. 1, d. 12702, t. 1, l. 23).

The significance of what happened is quite obvious: a priest ( $p o p$ ) "visits" an apartment with a teapot of holy water, and to the schoolchildren and pioneers this is already an oddity, evoking laughter. And to the priest the look of the pioneer girl who, by the way, is going about wearing a pioneer neck scarf in the apartment, that is, in her own home, is another oddity and most annoying. Here everyday life has plainly been rent asunder; the proverbial "reciprocity of perspectives" of A. Schütz is absent, provoking conflict - neither side demonstrates customary, expected behavior. (See Schütz 1988.) In its apparent lack of artifice, this

5. "In Maksimov's parish there worked a collective farm foreman who during an illness saw a vision 'in which all the collective farm workers were suffering, and the individual farmers were rejoicing.' This foreman asked for the priest Maksimov as if for confession, and also summoned all the workers of his brigade, to whom he said that they - the collective farm workers - should all leave the collective farm straightway, and shortly after confession the foreman died" (PermGANI, f. 643/2, op. 1, d. 28183, t. 2, 1l. 95-96).

6. In this report the policeman uses mainly a colloquial term for "priest" ( $p o p$ ) that by the mid-nineteenth century had become a pejorative. The standard, neutral term is sviashchennik - Translator. 
scene (the priest and the pioneer girl), as if lit up by a photographer's flashbulb, brings to mind the classics of that era: "All this - tractors and camels - went together very well in a picture frame under the title 'Old and New' or 'Who Whom?”' (Il'f and Petrov 1979, 558).

Another instance of a boy's appearance as a child took place in 1934 in the Alexandrovsky settlement: "yes, there was a case in 1934, when some youngsters went into Kholmogorov's vegetable garden. The priest's wife ambushed them in the garden and, seeing a boy, cried out: 'I caught the carrot thieves," for which they put the whole Kholmogorov family on trial (PermGANI, f. 641/1, op. 1, d. 16996, 1l. 72-75). They tried the priest ( $p o p$ ) and his wife (popad'ia) precisely because the boy turned out to be not a "carrot thief" but a pioneer. Here again there is a conflict, and what is more, a double one: first, the Kholmogorov family (actually - Kolmogorov) opposed the "carrot thief"; second, the authorities, asserting the new norm, opposed the priest and his wife. Evidently, the standard relation to childhood being introduced into everyday life (that is, in fact, the construction of childhood) as a "pioneer-schoolchild" stage happened right before the eyes of one generation and proceeded in utterly predictable fashion - traumatically.

Having studied the construction of childhood based on materials from Saratov province, Olga Bendina, for example, has drawn an analogous conclusion. There, beginning in the second half of the 1920 s until about 1934-35 inclusively, the shaping of the Soviet "first age" occurred, indirectly and tortuously, in several areas at the same time. (See Bendina 2007.) This was in fact an "expansion" of power in everyday life. A campaign to "attract children to school" became the first line of action. The second was the expansion of parents' responsibility (right up to judicial-administrative accountability) for "child neglect." The third was the training of cadres of educators and teachers, the fourth consisted of measures for the "strengthening of the family," and the fifth - the formation of normative pedagogical discourse, and so forth.

Not long before the beginning of the Second World War the Soviet regime completely won the struggle with the family for childhood, that is, for the disciplined and ideologized child. And indeed as early as 1934 a young woman living in Kungursky district, Akulina Blinova, rightly says about herself: "From childhood I have been working for different people as a housemaid" (PermGANI, f. 643/2, op. 1, d. 28183, t. 2, ll. 123-24 ob.). This already sounds like a grievance and a complaint - "exploiters deprived me of my childhood."

The second age began differently for men and women. All men in the second and third age unanimously mark their conscription into the 
army as a turning point in life, dividing it into a before and after: "In 1899 I graduated from the village school and I worked on my father's land without interruption until I was called up, that is until 1909" (PermGANI, f. 643/2, op. 1, d. 28183, t. 2, ll. 39-42); "In 1915 they took me into the old army, where I served until 1917 inclusively as an enlisted man" (PermGANI, f. 643/2, op. 1, d. 28183, t. 2, ll. 2-4); "In 1895 they mobilized me into the tsarist army, where I served until 1898 as an enlisted man" (PermGANI, f. 643/2, op. 1, d. 28183, t. 1, ll. 162-63). Typically, even an unrealized call-up became a milestone in one's biography:

I was born into a middling peasant family and until the age of twentythree I lived and worked on my father's land back home. They released me from the draft and enrolled me as a militiaman of the second category - this was in the twenty-third year after my birth. Having been released from the call-up for military service, in about 1894, I decided to go to monasteries and holy places to pray to God (PermGANI, f. 643/2, op. 1, d. 28183, t. 1, ll. 117-18).

For women marriage served as an analogous turning point, or, in cases in which that was not possible, transformation into a bride of Christ: "I, M. G. Kotel'nikova, was born in 1875 in the small village of Nistukovaia (Perm district, the Lobanovsky village soviet). Until the age of eighteen I lived as a peasant. Our household was a poor one. After the death of my father my mother advised me to go to a convent, since she was not in a position to give me in marriage" (PermGANI, f. 641/1, op. 1, d. 8768, t. 1, 1. 14).

Let me state a necessary qualification - once a pioneer (school-going) childhood and a Komsomol (higher education) youth have been established and become familiar in the lifeworld, once they become everyday phenomena, the nature of milestones-transitions necessarily undergoes a transformation ("You passed the strength of materials course - you can get married"). Perhaps this topic merits special investigation. But if the question is the mentality of mature, adult people who lived in the first half of the twentieth century in the Perm hinterlands, then it is surprising to observe that they easily "do not notice" events of world significance - the Russo-Japanese War, the revolution of $1905-7$, the fall of the monarchy and the like - but they remember precisely the moment of their call-up and demobilization, or, in the "female" version, marriage.

Perhaps the process of transition into the second age was memorable also because signs clearly emerge that confer the characteristics 
of an archaic initiation rite on the transition: a change of name (instead of "Grigory Ivanovich" - "Private Sokolov"), a change of attire (a soldier's uniform, the dress of a married woman, a religious habit), a transfer from one authority to another (from "father-batiushka" to "tsar-batiushka, "husband-batiushka"), ${ }^{7}$ and even a certain alteration of such physical attributes as hair (they cut the hair of new conscripts, they tonsure monks, they unplait the braids of a maiden).

The transition to the third age ("old man," "old woman") was less pronounced although also noticeable. Here a close acquaintance of Foty (sometimes in the text, Fotei) Petrov (Petrov was sixty-three years old) shares an observation: "Earlier, a year or two ago, Fotei Mikhailovich spoke well and read sermons, but, look, now he is already getting old; he's already so old that he doesn't spread the news as he did before, although he also goes around the villages with sermons" (PermGANI, f. 643/2, op. 1, d. 28183, t. 2, 1l. 85-87). This statement presents in compact form the essence of the perception of declining years. Foty, who himself defined his occupation with the word "wanderer," "worked" in a very specific job - he was a sort of mobile radio transmitter. He must have relayed the news beautifully ("well"). And now in the last year he can no longer handle this work, which means his bodily and spiritual strength are deserting him. That is - he has grown old. It was not, as people would say now, "Old age set in, he retired - and having weakened, the ailments of old age appeared," but in contrast: "He became weak - that means, old age had come. He became old."

In addition, the advent of the third age of life also had this everyday meaning, the appearance of infantile traits in the person's behavior - for example, dependence on milk. This is the kind of information an unknown witness reports about the priest Potap Osievich Kiselev (age sixty-five): "He rarely left his house; he kept to himself. When you do see him he grumbles about the authorities and especially that they took his last cow, for 'without milk I can't live, I'm an old man,' he says" (PermGANI, f. 643/2, op. 1, d. 29374, special envelope).

The aged need care as a little child does, and moreover, it is as if they were drifting away, becoming alienated from those closest to them, because of their infirmity dropping out of the circle of the familiar daily routine; they live on what their relatives and good people give them. The hermit monk Iosaf (Nikita Belousov) describes a la-

7. Batiushka is a traditional folk expression for "father" - Translator. 
dy's age in exactly this way: "A woman pilgrim Evdokiia came to him (she is now sixty years old, a decrepit old woman, who left for Viatsky district to find food two months ago, more precisely - a month and a half)" (PermGANI, f. 643/2, op. 1, d. 28183, t. 2, ll. 24-28).

The materials at my disposal do not permit any interpretation of the phenomenon of an individual's death, although this event undoubtedly appears on the horizon of the lifeworld and in some way, naturally, fits into everyday life, acquiring symbols and rituals, and always having a certain meaning. There is a single mention of the funeral of Bishop Ioaniky, but in the context of internal conflict - a certain priest at the funeral stood to the side separately from all the clergy, and there were numerous laconic remarks such as "he has now died" or "the deceased." Only once, speaking for some reason to an NKVD investigator about the sect of the "Semenushki," the priest Ivan Kotel'nikov (getting confused in his testimony, in the truest sense of the word) declares:

Semen Gladil'shchikov, with the surname "Semenushka," he comes from the little village Novaia in Kungursky district. Recently about forty people lived in this cell in the village of Zhuravlev. As I know, Gladil'shchikov reportedly died at that time. But when he died, I don't know. A prosperous peasant from the village Veslianka in the same village soviet (Kungursky district), Yakov Konstantinovich (I don't know his surname), joined this sect. Gladil'shchikov died in 1926, and a citizen member of this sect, Nikolai Ivanovich (whose last name I don't know) - he comes from the village Shchelchka in the Vesliansky village soviet in Kungursky district - washed his body. After Gladil'shchikov's death his cross was put on Nikolai Ivanovich who, it seemed, was worthy to be Semen Gladil'shchikov's successor. (PermGANI, f. 641/1, op. 1, d. 8768, t. 1, l. 28-28ob.)

The simple symbolism here is very typical of a traditional society the passing on of a cross as the passing on of one's fate, one's destiny ("It is for you to bear my cross").

Conceivably, prevailing expectations of a universal finale, of the completion of the world cycle, help one to understand the meaning of an individual life's finiteness. I refer to the experience of living through the "last times" and the "end of the world" - the third modality of the perception of time at the everyday level. This concern is deeply colored by Christian eschatology, surrounded frequently by reinterpreted biblical quotations, and supplied with numerological underpinnings. The 
temptation exists to link expectation of the end of the world and the "last times" with the influence of religious ideology, which, no doubt, constitutes an important element of a traditional mentality. But there are grounds for, and most importantly, the possibility of, differentiating between the phenomenological sense of the last times and its secondary trajectory in the ideological sphere.

Note, for example, a book (a general school notebook with graph paper) with the title "The Fate of Russia" (figure 1), preserved in the file of the priest I. I. Kotelnikov, "a book written by him in his own hand," as the book is entitled in the file's materials. In the book the priest calculates precisely the year of the end of the world - and we can do it together with him. Combining the digits in the written year $1935(1+9+3+5)$ gives the answer "18." But 18 is three sixes $(6+6+6)$, and " 666 " is the number of the beast in the "Book of Revelation."

Further: Converting the year 1935, reckoned from the birth of Christ, into the old reckoning system "from the creation of the world" $(1935+5508)$ gives the year 7443 . Combining the digits $(7+4+4+3)$ once again gives 18. Ergo, the end of the world was appointed by Providence (and enciphered in digits) for 1935 .

But Kotelnikov himself and people who had personally interacted with him said something else:

The directives I gave were the following: 1) to spread rumors of the end of the world and the fall of the Soviet regime in 1933 among the population with the purpose of waging a struggle with increasing godlessness (PermGANI, f. 643/2, op. 1, d. 28183, t. 2).

In 1932 Kotelnikov began to say to me again that the time was drawing near when it was necessary to be especially vigilant. That of the twentyeight signs of the coming of the antichrist according to holy scripture only two had not come to pass: 1) the utter abomination of desolation in the holy place, that is, the complete destruction and desecration of the churches and 2) the coming itself of the antichrist. But this scripture must be fulfilled in its entirety no later than 1933 (PermGANI, f. 643/2, op. 1, d. 28183, t. 1, 1l. 97-102).

On October 6, 1932, I was visiting Ovchinnikov, and he said to me in conversation that the psalmist at the church in Podavikha, Nikolai Yakovlevich Alekseev, was spreading rumors among the believers of the village of Podavikha that the world would end soon, indicating the date that the world would end as the beginning of 1933 or at Easter - MarchApril 1933. (PermGANI, f. 641/1, op. 1, d. 8768, t. 1, ll. 23-24) 


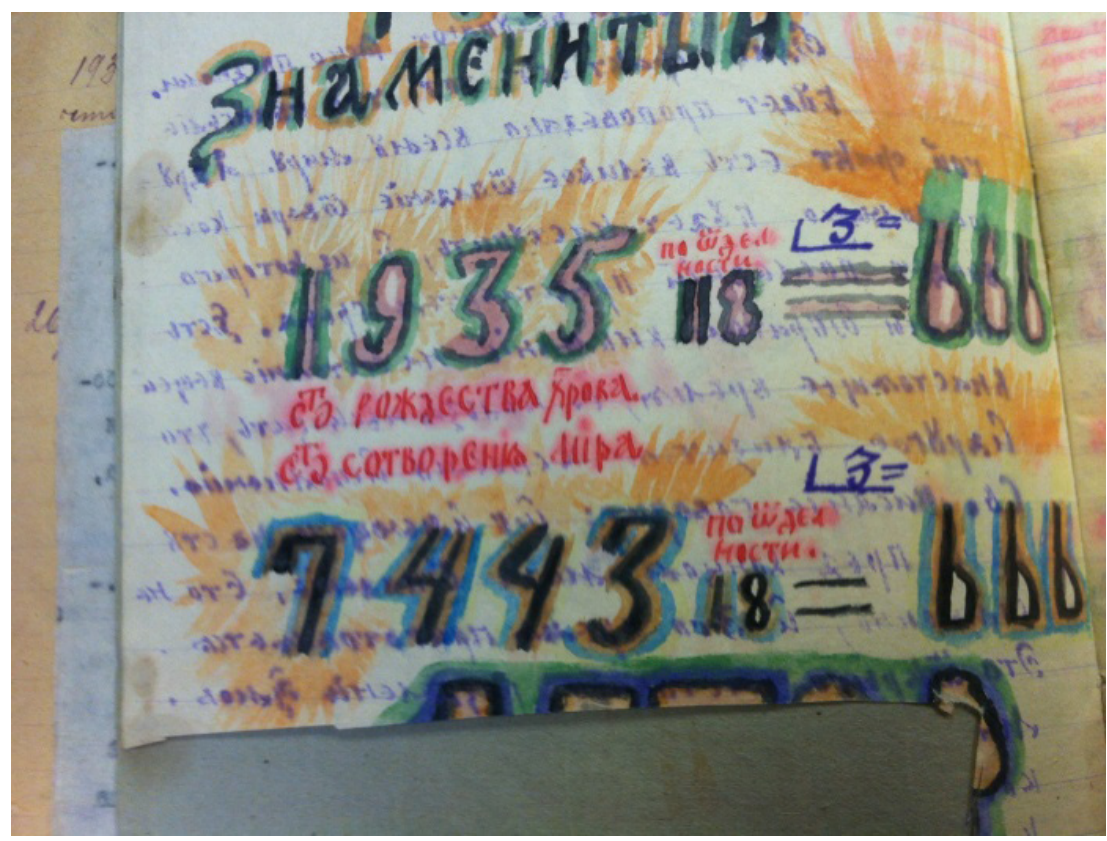

Figure 1. Calculation of the date of the end of the world by the priest I. I. Kotelnikov. The manuscript was written ca. 1932.

It was this very period - the end of 1932 and the beginning of 1933 - that lay at the root of a whole series of practices recorded in completely reliable sources. Several people, independently of each other, speak of strange "assemblies for heaven" observed in the village of Podavikha. The priest Varlaam Zomarev testifies: "The spread of rumors about the imminent end of the world by Alekseev among the believers had certain consequences: The faithful of the village Podavikha sewed clothes for themselves and knapsacks, preparing for death, as if they would flee somewhere but where - I did not know" (PermGANI, f. $641 / 1$, op. 1, d. 8768, t. 1, ll. 23-24). And note this excerpt from the "Indictment in the case of I. I. Kotel'nikov and others":

In October 1932 the priest [pop] OVCHINNIKOV and the psalmist ALEKSEEV spread rumors among the population about the end of the world in January 1933. The citizens of the hamlet of Podovikha, preparing for death, sewed white garments for themselves, the better to pray for forgiveness of their sins before death, and they went many versts to pray, in particular to Kishertsky district, to the village Moriakovo to the priest [pop] KOTEL'NIKOV. (PermGANI, f. 643/2, op. 1, d. 28183, t. 2, 1l. 6o-71) 
It is surprising that in the given case the numerological exercises indicating 1935 and the actual expectations of the end of the world, leading to quite substantive effects, were, first, chronologically inconsistent, and, second, linked with one and the same personage - the priest Ivan Kotelnikov. I shall try to sort this out.

The end of the world first began to dawn on the lifeworld horizon of village inhabitants in the Urals in about 1930:

Belozerov spread defeatist rumors as early as 1930, at one of the counterrevolutionary gatherings in the Asov church. Other people and I were talking together with G. I. Belozerov and I asked him: "Grigory Ilich, tell me, aren't the last times beginning?" Belozerov answered me: "At present this must not yet be, for this regime must be changed, these authorities will be no more; then the star will be not five-pointed, but six-pointed." (PermGANI, f. 641/1, op. 1, d. 16925, t. 2, l. 410b.)

The impression takes shape that a vivid sense of "the last times" and the imminent arrival of the Antichrist reached a peak of intensity at the end of 1932 and the beginning of 1933, but then gradually died out. By 1937 no one was talking about the end of the world, but rather they were hoping for the fall of the Soviet regime as a result of Japanese or German intervention and the world war. (For more details on this, see Kazankov 2011.)

What exactly lies behind this short-lived but very vivid, intense experience of time as "the last time"? To assert that religious doctrine provoked it, that it was predicted in scripture, is somewhat like saying: "Today it is warm, because the thermometer reads thirty degrees Celsius in the shade," that is, to reverse cause and effect. Another explanation is more likely - a specific traumatic experience required the mobilization of all the explanatory possibilities of religious teaching, by becoming the center of the crystallization of eschatological expectations. (See Panchenko 2002.) It is not difficult to surmise what sort of experience this was, and on this point the interpretation of time I originally proposed also intersects very smoothly with space, forming a sensory-specific chronotope. Clearly, the time was "depraved" and "coming to an end" not in itself but because the collective farm invaded the space of everyday life.

The first signs of the grand campaign preparing for the collectivization of the village appeared in the summer of 1929, and by November the government's intentions had become evident. The reaction was not long in coming. In November 1929, during questioning about counterrevolutionary agitation by the local clergy, a young peasant sympathet- 
ic with the Soviet regime and also managing the village reading room in Brusun (Chusovsky district) reports:

The church people themselves, such as the deacon Mikhail and the monk Paisy, more than once came to the village and had conversations in the street with the peasants along the lines of the following: "Laypeople! The atheists have come up with the idea to draw us Orthodox Christians with their lying deceptive talk into their vile organizations - the communes. Don't think of signing up for these heretical collectives; there you will be cursed by our holy fathers. There all the possessions you have acquired by your sweat and blood will be taken from you. You will work for these bums (galakhi). ${ }^{8}$ They're not willing to do honest work, for they, the thieves, have dreamed up the idea of enslaving you workers of the land in service to the devil. They have neither cross nor conscience. Don't trust them. They will forbid you to come to our holy church and will mock our Orthodox faith. With them you will have prolonged famine; you will go around the commune with your sack. (PermGANI, f. 641/1, op. 1, d. 8891, l. 8-8ob.)

The characteristics of the collective farm as a sort of "anti-place," an "antichrist" place, can be given in more detail in another project. Here I need only denote the core of the traumatic experience that produced the sense of the "last times." A range of witnesses indicates that something oppressive, coercive, and overwhelming broke brutally and aggressively into everyday life. In the words of the priest Vasily Michkov, brought to us by an anonymous informer under the pseudonym "Green," there is a pair of completely eidetic (and self-interpreted) images: the image of the "box," into which the "Jews bend the peasants" and the "screw" with the help of which they wring out money and bread (PermGANI, f. 641/1, op. 1, d. 12702, special envelope). Or, for example, one of the surviving individual farmers, the farmer (khutorianin) Timofei Shvetsov, explained the advantage of his position thus: "To live on one's own is hard because they crush you with crippling taxes, but, nevertheless, somehow we squeeze out the money and pay this amount expected from us, and again I am at peace and no one is running under the window and driving you out to work" (PermGANI, f. $641 / 1$, op. 1, d. 12702, special envelope). In contrast to the collective farm laborer the individual farmer was free - and therefore at peace.

The accustomed, that is, the everyday, way of life of the peasant presupposed a certain minimum of private autonomy, albeit expressed

8. Galakh is an epithet in the Urals for those without families, drunkards, tramps. 
in the primitive formulation "no one is running under the window and driving you out to work." In the collective farm there was no freedom, and there was a "screw" with a good, strong grip. Peasants living in the Urals in the 1930 s literally "felt [this] in their skin." And he who is not free cannot be a member of Christ's church. This was the first, essential element of the experience of the "last times," of "depraved" times, in which it's impossible to live, in which the familiar everyday meanings have come to an end.

The second element was the perception of the futility of the free, unpaid labor of the collective farm workers, their absolute destitution: "There is almost nothing to eat, all the bread goes to the state, they earn money - they also pay taxes, and they sit without bread among their own grain; work alone remains" (PermGANI, f. 641/1, op. 1, d. 12702, special envelope). One of the specific characteristics of everyday life is that it is an arena of equivalent exchanges, a place where an honest game of "sacrifice and reward" is played. What was happening on the collective farm meant the collapse of everyday routine, the establishment of something utterly absurd but unstoppable, advancing triumphantly.

I shall try to state briefly what I saw when looking at the experience of time. First and foremost, the "spiritual equipment" of the inhabitant of the provincial hinterlands right up to the end of the 1930s was attuned to the small-scale (church-holiday) annual cycles that seamlessly flowed and combined into the distinct, visible "three ages of life" that broadly typify the culture of traditional societies. The intrusion of modernization in this instance is sensed only in the conflicts and discord of "reciprocal perspectives" that surrounded the establishment of a childhood of pioneers and school, "introduced" by the regime into everyday life literally right before the eyes of a single generation. This was a new and shocking experience.

But also, for "traditional time" itself, as they say, "the times had been fulfilled." The chief cultural shock, imprinted in the image of the "last times," proved to be the collective farm. The "last times" was not at all a church metaphor but the phenomenon of perceiving that everyday life was collapsing, splitting apart, and disintegrating under the

9. See Syrov 2000: "This is why one should not link everyday life with a totally consumerist and egoistical relation to the world. Routine, monotony, sacrifice, and limitation are present in everyday life when limits are placed on desire. But they are dependent not on internal control but on the force and opposition of external objects. Therefore it is possible to consider the relationship of exchange as the relationship describing this particular dialectic of interaction with the world. Everything makes sense only when it is fit together in this formula: I give and I receive. Here an inversion is possible, when an intentional sacrifice is made with the purpose of prompting and enhancing the act of receiving." 
influence of collectivization. This was a very involved, complex experience: the sense of "normal" time as the possibility of free choice and equivalent exchange, on the one hand, and the perception of the end of comprehensible existence as "troubled times," on the other, were tightly intertwined, as well as tinged with religious eschatological symbolism, and, as has become clear, became a quite tangible force changing everyday behavior ("assemblies for heaven").

\section{References}

Archival Sources

Permskii gosudarstvennyi arkhiv noveishei istorii [Perm State Archive of Contemporary History (hereafter PermGANI)], f. 641/1 (Arkhivnye ugolovnye dela na lits, sniatykh s operativnogo ucheta v Informatsionnom Tsentre Upravelniia Vnutrennikh Del Permskogo oblispolkoma [Archival criminal files on individuals, taken from the operational records of the Information Center of the Internal Affairs Department of the Perm Oblast Executive Committee]), op. 1, d. 8768, t. 1, 1. 10-10ob., note by I. Kotel'nikov on a conversation with a bishop.

PermGANI, f. $641 / 1$, op. 1 , d. 8768 , t. 1 , 1. 14, report on the interrogation of the accused M. G. Kotel'nikovaia, December 31, 1932.

PermGANI, f. $641 / 1$, op. 1, d. 8768, t. 1, 1l. 18-19ob., report on the interrogation of the accused F.A. Naumov, December 31, 1932.

PermGANI, f. $641 / 1$, op. 1, d. 8768 , t. 1, ll. 23-24, report on the interrogation of the witness V.V. Zomarev, January 1, 1933.

PermGANI, f. $641 / 1$, op. 1, d. 8768, t. 1, 1. 28-28ob., report on the interrogation of the accused I.I. Kotel'nikov, January 2, 1933.

PermGANI, f. $641 / 1$, op. 1, d. 8891, 1. 8-8ob., report on the interrogation of the witness I. I. Neustroev, November 19, 1929.

PermGANI, f. $641 / 1$, op. 1 , d. 8891 , 1. 14, report on the interrogation of the witness S.V. Tret'iakov, November 19, 1929.

PermGANI, f. 641/1, op. 1, d. 12702, special envelope, the source "Cheremukhin" on a conversation with T. Shvetsov; report to the head of the Uinskii district office of the NKVD in Sverdlovsk Oblast and sergeant in State Security Emel'ianov, January 11, 1937.

PermGANI, f. 641/1, op. 1, d. 12702, special envelope, the source "Green" on a conversation with V. Michkov; report to the head of the Uinskii district office of the NKVD in Sverdlovsk Oblast and sergeant in State Security Maliutin, October 6, 1934.

PermGANI, f. 641/1, op. 1, d. 12702, t. 1, l. 23, report to the head of the NKVD in Ordinsky district from Kiriakov, a policeman in the first precinct, February 4, 1935.

PermGANI, f. $641 / 1$, op. 1, d. 12702, t. 1, l. 113ob., report on the interrogation of the witness P.V. Novoselovaia, September 4, 1937.

PermGANI, f. $641 / 1$, op. 1, d. 12702, t. 1, l. 135, inventory of the property in the personal possession of S. A. Nekrasov.

PermGANI, f. 641/1, op. 1, d. 12702, t. 1, 1. 251, inventory of the property in the personal possession of P. A. Shliapnikov.

PermGANI, f. 641/1, op. 1, d. 16925, t. 2, l. 41ob., confrontation of the accused G. I. Belozerov with the accused M. D. Khripunovaia, August 19, 1937. 
PermGANI, f. $641 / 1$, op. 1, d. 16996, ll. 72-75, report on the interrogation of the accused A. M. Mekhanoshinaia, April 26, 1937.

PermGANI, f. 643/2 (Arkhivnye ugolovnye dela na lits, reabilitirovannykh po Ukazu Prezidiuma Verkhovnogo Soveta SSSR ot 16.01.1989 i Zakonu RSFSR ot 18.10.1991 [Archival criminal files on individuals rehabilitated by the Decree of the Praesidium of the Supreme Soviet of the USSR of January 16, 1989, and the Law of the RSFSR of October 18, 1991]), op. 1, d. 28183, t. 2, typewritten copy of the testimony of the accused I. I. Kotel'nikov, February 21, 1933.

PermGANI, f. $643 / 2$, op. 1 , d. 28183 , t. 1, 1. 14, report on the search and arrest of Fotii Mikhailovich Petrov, May 4, 1934.

PermGANI, f. $643 / 2$, op. 1 , d. 28183 , t. 1 , ll. $82-87$, report on the interrogation of the accused M.N. Morskovatykh, May 4, 1934.

PermGANI, f. $643 / 2$, op. 1 , d. 28183 , t. 1 , ll. $88-96$, report on the interrogation of the accused M.N. Morskovatykh, May 25, 1934.

PermGANI, f. $643 / 2$, op. 1 , d. 28183 , t. 1, ll. 97-102, additional testimony of the accused M. N. Morskovatykh, June 25, 1934.

PermGANI, f. $643 / 2$, op. 1 , d. 28183 , t. 1 , ll. 117-18, report on the interrogation of the accused F. M. Petrov, May 13, 1934.

PermGANI, f. $643 / 2$, op. 1 , d. 28183 , t. 1 , ll. $144-45$, report on the interrogation of the accused V.E. Maksimov, May 15, 1934.

PermGANI, f. $643 / 2$, op. 1, d. 28183 , t. 1, ll. 151-54, additional testimony of the accused V.E. Maksimov, May 23, 1934.

PermGANI, f. $643 / 2$, op. 1 , d. 28183 , t. 1, ll. 162-63, report on the interrogation of the accused, I. I. Osetrov, May 12, 1934.

PermGANI, f. $643 / 2$, op. 1 , d. 28183 , t. 2 , typewritten copy of the testimony of the accused I. I. Kotel'nikov, February 21, 1933.

PermGANI, f. 643/2, op 1, d. 28183, t. 2, ll. 2-4, report on the interrogation of the accused P. G. Solin, May 15, 1934.

PermGANI, f. $643 / 2$, op. 1, d. 28183 , t. 2, ll. 24-28, additional testimony of the accused N. V. Belousov, June 25, 1934.

PermGANI, f. $643 / 2$, op. 1 , d. 28183 , t. 2 , ll. $39-42$, report on the interrogation of the accused G. I. Sokolov, September 11, 1934.

PermGANI, f. 643/2, op. 1, d. 28183, t. 2, 1l. 60-71, excerpt from the indictment in case no. 11141 on the accusation of I. I. Kotel'nikov, I. A. Ovchinnikov, N. Ia. Alekseev, F.A. Naumov and twenty-seven others.

PermGANI, f. $643 / 2$, op. 1 , d. 28183 , t. 2 , ll. $85-87$, report on the interrogation of the witness G. Ia. Rusanov, May 10, 1934.

PermGANI, f. $643 / 2$, op. 1, d. 28183 , t. 2, ll. 95-96, additional testimony of the witness P.P. Kuznetsovaia, May 14, 1934.

PermGANI, f. 643/2, op. 1, d. 28183, t. 2, ll. 123-24ob., report on the interrogation of the witness A. T. Blinovaia, May 22, 1934.

PermGANI, f. 643/2, op. 1, d. 29374, special envelope, memorandum on P. I. Kiselev.

\section{Secondary Sources}

Ariès, Philippe. 1999. Rebenok i semeinaia zhizn' pri Starom poriadke [Centuries of Childhood: A Social History of Family Life]. Ekaterinburg: Izdatel'stvo Uralskogo universiteta. 
Astakhova, Larisa. 2013. "Interpretativnaia antropologiia Klifforda Girtsa: religioznye praktiki kak seti znachenii [Clifford Geertz's interpretive anthropology of religion: Religious practices as webs of meaning]." Gosudarstvo, religiia, tserkov'v Rossii i za rubezhom 31 (3): 162-77.

Beglov, Aleksei. 2008. V poiskakh "bezgreshnykh katakomb”. Tserkovnoe podpole v SSSR [In search of "sinless catacombs": The underground church in Soviet times]. Moscow: Izdatel'skii Sovet Russkoi Pravoslavnoi Tserkvi, Arefa.

Bendina, Ol'ga. 2007. “'Chem rebiat branit' i bit', luchshe knizhku im kupit'!: diskursy zhestokogo obrashcheniia s det'mi v 1920-30-e gody (na materialakh Saratovskoi gubernii)." In Sovetskaia sotsial'naia politika 1920-193o-kh godov: ideologiia i povsednevnost' ['Instead of Swearing at Children and Beating Them, It is Better to Buy Them Books!': Discourses of Child Abuse in the 1920s-1930s (Based on Materials from Saratov Province). In Soviet social policy in the 1920s-3os: Ideology and everyday life], edited by Pavel Romanov and Elena Iarskaia-Smirnovaia]. Moscow: OOO "Variant," TsSPGI.

Ginzburg, K. [Carlo]. 200o. Syr i chervi. Kartina mira odnogo mel'nika, zhivshego v XVI $v$. [The Cheese and the Worms: The Cosmos of a Sixteenth-Century Miller]. Moscow: "Rossiiskaia politicheskaia entsiklopediia" (ROSSPEN).

Il'f, I. A. and E. P. Petrov. 1979. "Zolotoi telenok." In Dvenadtsat' stul'ev [The golden calf. In The twelve chairs]. Ordzhonikidze: Ir.

Kazankov, Aleksandr I. 2011. "Portret terrorista v perspektive 1937 g." In Istoriia stalinizma: repressirovannaia rossiiskaia provintsiia. Materialy mezhdunarodnoi nauchnoi konferentsii. Smolensk, 9-11 oktiabria $2009 \mathrm{~g}$. [Portrait of a terrorist from the perspective of 1937. In The history of Stalinism: The repressed Russian province. Materials of an international scientific conference, Smolensk, October 9-11, 2009], edited by E. V. Kodin. Moscow: ROSSPEN.

Kondrashina, Elena. 2014. "Zhenshchina v obshchinnoi zhizni protestantskikh tserkvei v SSSR (1945-1991)" [Women in the communal life of Protestant churches in the Soviet Union (1945-1991)]. Gosudarstvo, religiia, tserkov'v Rossii i za rubezhom 32 (1): $151-71$.

Le Goff, Jacques. 2005. Tsivilizatsiia srednevekovogo Zapada [Medieval civilization, 40o1500]. Ekaterinburg: U-Faktoriia.

Le Roy Ladurie, Emmanuel. 2001. Montaiiu, oksitanskaia derevnia (1294-1324) [Montaillou: The Promised Land of Error]. Ekaterinburg: Izdatel'stvo Uralskogo universiteta.

Panchenko, A. A. 2002. Khristovshchina i skopchestvo: fol'klor i traditsionnaia kul'tura russkikh misticheskikh sekt [The "Christ-faith" and the "self-castrators": Folklore and the traditional culture of Russian mystical sects]. Moscow: OGI.

Protsenko, Pavel G. 2010. V Nebesnyi Ierusalim. Istoriia odnogo pobega. (Biografiia episkopa Varnavy/Beliaeva). 2 izd. [To the heavenly Jerusalem: The story of an escape (The biography of Bishop Varnava (Beliaev). 2nd edition]. Nizhnii Novgorod: Izdatel'stvo Khristianskaia biblioteka.

Shchiuts [Schütz], A. 1988. "Struktura povsednevnogo myshleniia" [The structure of everyday thinking]. Sotsiologicheskie issledovaniia 2.

Syrov, V. N. 2000. "O statuse i strukture povsednevnosti (metodologicheskie aspekty) [On the status and structure of daily routine (methodological aspects)]." In Lichnost'. Kul'tura. Obshchestvo. T. 2 [Identity, culture, society. Vol. 2], 147-59. Special edition. 